20. Perfect JR, Lang SD, Durack DT. Chronic cryptococcal meningitis: a new experimental model in rabbits. Am J Pathol. 1980;101:177_ 94.

21. Kwon-Chung KJ, Bennett JE, Rhodes JC. Taxonomic studies on Filobasidiella species and their anamorphs. Antonie Van Leeuwenhoek. 1982;48:25-38.

22. Lengeler KB, Cox GM, Heitman J. Serotype AD strains of Cryptococcus neoformans are diploid or aneuploid and are heterozygous at the mating-type locus. Infect Immun. 2001;69:115-22.

23. Varma A, Wu S, Guo N, Liao W, Lu G, Li A, et al. Identi? cation of a novel gene URE2 that functionally complements a urease negative clinical strain of Cryptococcus neoformans. Microbiology. 2006;152:3723-31.

24. Swofford DL. PAUP*: Phylogenetic analysis using parsimony (*and other methods). Version 4. Sunderland (MA): Sinauer Associates, Inc.; 2002.

25. Bell M, Archibald LK, Nwanyanwu O, Dobbie H, Tokars J, Kazembe P. et al. Seasonal variation in the etiology of bloodstream infections in a febrile inpatient population in a developing country. Int J Infect Dis. 2001;5:63-9.

26. Franzot SP, Salkin IF, Casadevall A. Cryptococcus neoformans var. grubii: separate varietal status of Crytococcus neoformans serotype A isolates. J Clin Microbiol. 1999;37:838-40.

27. Barreto de Oliveira MT, Boekhaut T, Theelen B, Hagen F, Baroni FA, Lazera MS, et al. Cryptococcus neoformans shows a remarkable genotypic diversity in Brazil. J Clin Microbiol. 2004;42:1356-9.

28. Jain N, Wickes BL, Keller SM, Fu J, Casadevall A, Jain P, et al. Molecular epidemiology of clinical Cryptococcus neoformans. J Clin Microbiol. 2005;43:5733-42.

29. Dromer F, Mathoulin S, Dupont B, Laporte A. Epidemiology of cryptococcosis in France: a 9 year survey (1985-1993). French Cryptococcosis Study Group. Clin Infect Dis. 1996;23:82-90.

30. Hajjeh RA, Conn LA, Stephen DS, Baughman W, Hamill R, Graviss E, et al. Cryptococcosis: population-based multistate active surveillance and risk factors in human immunode? ciency virus-infected persons. Cryptococcal Active Surveillance Group. J Infect Dis. 1999;179:449-54.
31. Moosa MYS, Coovadia YM. Cryptococcal meningitis in Durban, South Africa: a comparison of clinical features, laboratory ? ndings, and outcome for human immunode? ciency virus (HIV)-positive and HIV-negative patients. Clin Infect Dis. 1997;24:131-4.

32. Chen S, Sorrell T, Nimmo G, Speed B, Currrie B, Ellis D, et al. Epidemiology and host-and variety-dependent characteristics of infection due to Cryptococcus neoformans in Australia and New Zealand. Clin Infect Dis. 2000;31:499-08.

33. Meletiadis J, Walsh TJ, Choi EH, Pappas PG, Ennis D, Douglas J, et al. Study of common functional genetic polymorphisms of FCGR2A, $3 \mathrm{~A}$ and $3 \mathrm{~B}$ genes and the risk for cryptococcosis in HIV-uninfected patients. Med Mycol. 2007;45:513-8.

34. Casadevall A, Perfect JR. Cryptococcus neoformans. Washington: ASM Press; 1998

35. Friedman GD. The rarity of cryptococcosis in northern California: the 10-year experience of a large de? ned population. Am J Epidemiol. 1983;117:230-4.

36. Hajjeh RA, Conn LA, Stephens DS, Baughman W, Hamill R, Graviss E, et al. Population-based multistate active surveillance and risk factors in human immunode? ciency virus-Infected persons. J Infect Dis. 1999; 179:449-54.

37. Kwon-Chung KJ, Hill WB. Sexuality and pathogenicity of Filobasidiella neoformans (Cryptococcus neoformans). In: Vanbreuseghem R, DeVroey C, editors. Sexuality and pathogenicity of fungi. New York: Masson; 1981. p. 243-50.

38. Lo D. Cryptococcosis in the Northern Territory. Med J Aust. $1976 ; 2: 825,828$

39. Sorvillo F, Beall G, Turner PA, Beer VL, Kovacs AA, Kerndt PR. Incidence and factors associated with extrapulmonary cryptococcosis among persons with HIV infection in Los Angeles County. AIDS. 1997; 11:673-9.

Address for correspondence: Kyung J. Kwon-Chung, Molecular Microbiology Section, Laboratory of Clinical Infectious Diseases, National Institute of Allergy and Infectious Diseases, National Institutes of Health, Bethesda, MD 20892, USA; email: june_kwon-chung@nih.gov

\title{
etymologia
}

\section{Cryptococcus neoformans}

[krip" to-kok'əs ne"'o for-mənz], from the Greek-krypto (hidden),

kokkos (berry), neos (new); and Latin-forma (form)

C. neoformans is an encapsulated yeastlike fungus of the family Cryptococcaceae. It was ? rst described in 1894 by German pathologist Otto Busse, who observed the cells in a tumor from the tibia of a woman with sarcoma. Found worldwide in nests and droppings of pigeons, it is the most common species that causes cryptococcosis in humans. The effects range from asymptomatic infection to meningitis, pneumonia, or disseminated disease. The crucial factor is the immune status of the host. With the global emergence of AIDS, the incidence of cryptococcosis is increasing and now represents a major life-threatening infection in these patients.

Source: Dorland's Illustrated Medical Dictionary, 31st edition. Philadelphia: Saunders Elsevier; 2007; http://www.emedicine.com/ med/TOPIC482.HTM 